\title{
倒立振子型アシストロボット用軽量双腕マニピュレータの開発*
}

\author{
鄭 聖 喜*1, 木村 直*2, 高橋隆 行*1 $^{*}$
}

\section{Development of a Light-Weight Dual Manipulator for an Inverted Pendulum Type Assist Robot}

\author{
Seonghee JEONG*3, Sunao KIMURA and Takayuki TAKAHASHI \\ ${ }^{* 3}$ Department of Symbiotic Systems Science, Fukushima University, \\ 01 Kanayagawa, Fukushima-shi, Fukushima, 960-1296 Japan
}

\begin{abstract}
This paper proposes a light-weight dual manipulator with 8 D.O.F for an inverted pendulum type assist robot. The manipulator has been designed to be a light-weight one, 3 [kg], to assure safety and work ability, even it has 8 D.O.F and $1.75[\mathrm{~kg}]$ weight capacity. In order to realize various tasks by an inverted pendulum type robot some unique mechanisms are installed such as an extendable joint, a mechanical hinge stopper, and a wrist omni wheel. By using motion control with the mechanisms, the robot can achive various motions such as standing up and sitting down, picking an object on the ground, static traveling, handling a small object, and lifting a heavy object. A prototype manipulator and a control system were integrated and a basic operation experiment was performed.
\end{abstract}

Key Words: Dual Manipulatotr, Light-Weight Manipulator, Inverted Pendulum Type Assist Robot

\section{1. 緒言}

1.1 背景 近年, 二足型ヒューマノイドロボッ トに代表される, 人間の生活環境で様々な対人サービ スの提供を目的とする人間共存型ロボットの研究・開 発が活発に行われている.これらのロボットにおいて は, 人間や環境に対する高い安全性と, 軽作業から重 作業まで多様なサービスが効率よく実行できる高い作 業能力の両立が強く求められる. しかし, 両機能は一 般的に相反する性質を持ち，一つのシステムでそれら を同時に実現することは困難な課題である．この課題 に対して, 車輪駆動式倒立振子機構のロボットへの導 入は，両機能の両立を可能にする一つの有効な手段で あると考えられる，例えば，車体に同機構を用いる口 ボットは，人間のように重心を傾けることで自重を有 効に使った作業が可能であり, 非力なマニピュレータ でも高い可搬重量特性が実現できる. また, 機構自体 が他の移動方式に比べてシンプルであるため，安全性 向上の基本方策である軽量化が容易である.ささらに, 常時バランス制御を行うので，比較的重心の高い人間 型ロボットにおいて，予期しない衝突や接触に対する

* 原稿受付 2009 年 4 月 13 日.

*1 正員, 福島大学共生システム理工学類(馬 960-1296 福島市 金谷川01).

*2 福島大学共生システム理工学類.

E-mail : jeong@rb.sss.fukushima-u.ac.jp
転倒安全性が高く, 小フットプリント, キャスターレス 等の特徴から機敏な動作や高い段差登坂能力のメリッ 卜を持つ.これらの特徵から, 車輪駆動式倒立振子機 構は, 高安全性と高作業能力を必要とする人間共存型 ロボットに適した移動機構であると考えられる.

\section{2 関連研究これまでの車輪駆動式倒立振子} ロボットに関する研究は主に移動能力や倒立安定性に 関するものが多く ${ }^{(1)(2)(3)}$, 対人サービスの提供を目的と した研究は少ない，その中でBryan ら ${ }^{(4)}$ は，倒立振子 型ロボットが静的安定なロボットより外部環境へ大き な力を発生できることを示し, 松本ら ${ }^{(5)}$ は, 複数の倒 立振子型ロボットによる協調搬送方法を提案した。こ れらの研究に扔いては, 倒立振子機構自体がアームの 役割を果たすか， 2 自由度のシンプルなアームを同機 構に搭載した構成である. これに対し, 近年, RobovieIII $^{(6)}$, Emiew-1，2 $2^{(7)}$ のような移動機構として車輪式 倒立振子機構を用い, 上半身に腰や多自由度マニピュ レータを搭載した倒立振子型ヒューマノイドロボット も開発されている. Robovie-III は倒立振子のバランス 動作の対人効果の評価等を目的としており，マニピュ レータは主に印象評価用のジェスチャーを生成するの に用いられる. Emiew の場合は高速移動や案内を主に 行うが，多自由度マニピュレータを使って軽量物の運 びなどの作業も実行できる．しかし，これらのロボッ 


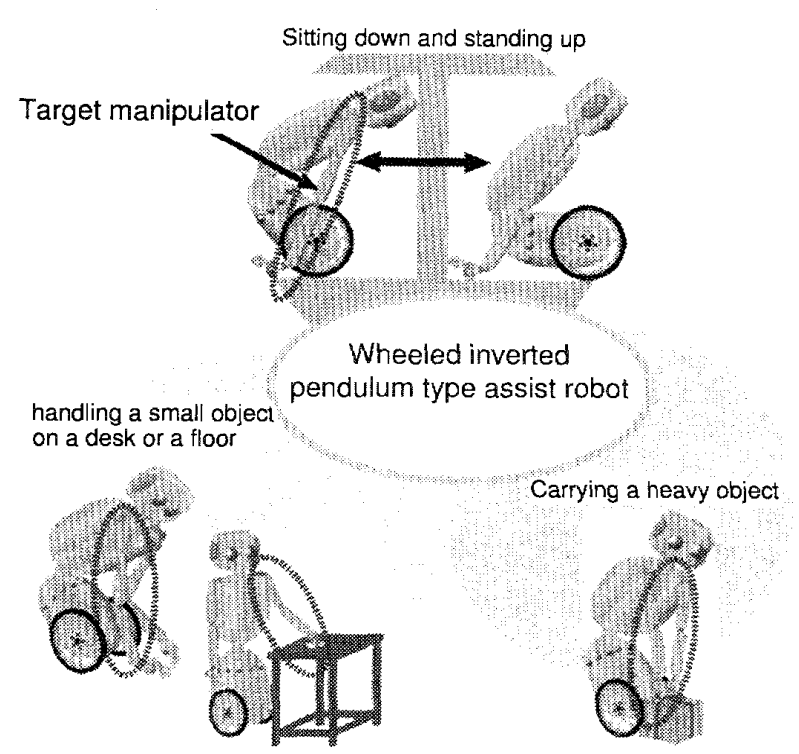

Fig. 1 Representative goal tasks by I-PENTAR

トに搭載されているマニピュレータは，産業用ロボッ トや 4 輪移動マニピュレータ等静的に安定なロボット 用と類似のものであり，機構的に不安定なロボットに 適したメカニズムであるとは言い難い．

1.3 本研究の目的 本研究では, 機構的に不安 定な倒立振子型ロボットが静的に安定なロボットと同 等, 又は, その機構的不安定性を活用した特有の作業 を安全かつスムーズに実行するための倒立振子型口 ボットに適したマニピュレータの開発を目的とする。 本稿では, 開発中の倒立振子型アシストロボット IPENTAR $^{(8)(9)(10)}$ への搭載を前提とした, 安全性及び作 業性を考慮した「倒立振子型アシストロボット用軽量 8自由度双腕マニピュレータ」について機構設計を中 心に述べる.

以降，2章では，I-PENTARを含む不安定ロボット 用に要求されるマニピュレータの機能について言及し, 3章にそれらの機能を実現するためのメカニズムを持 つマニピュレータについて機構を中心に述べる，4章 では，開発したマニピュレータの動作制御システム及 び簡単な動作実験を行った結果を述べる。

\section{2. マニピュレータに必要される機能}

人間共存環境下で詨人サービスを行うことを目的と するマニピュレータには，人間を傷つけない高い安全 性と多様なサービスが可能な高作業能力が要求される ことは上述した．本研究で開発するマニピュレータも 対人サービスの提供を目的とするため, 安全性と作業 能力は基本的に備えるべき機能である。これらの機能 の評価はマニピュレータの使用環境や実行タスクごと
に異なり，その実現方法も様々である，しかし，多く のマニピュレータシステムにおいて，両機能を実現す るために共通的に用いられる手法は幾つか存在する. その中で, 本研究では, 安全性に関しては軽量化 ${ }^{(1)}$ 及 び非力化，作業能力に関しては多自由度化 ${ }^{(12)}$ 及び車体 との協調動作を採用する. 軽量化及び非力化は，マニ ピュレータの潜在的危険源を減らし，リスクをできる 限り低減する本質安全設計の思想に基づいた手法であ り, 多自由度化牥タク実行時, 機構による自由度及 び作業領域の制約をできる限り受けないための手法で ある。これらの手法は, 倒立振子型ロボットに搭載さ れるマニピュレータに限られたものではなく, 人間支 援を目的とするマニピュレータにおいて，両機能を実 現するための重要な共通的な手段である.

倒立振子型ロボットは，その不安定さゆえに静的に 安定なロボットに比べ，実行が制約されるタスクが多 い．例えば，振動の影響を受ける細かな作業や，長時 間の待機等が不安定さやバランス制御の影響を受ける 代表的な作業である，倒立振子型ロボットに搭載され るマニピュレータは，倒立振子型ロボットの特性上実 行が困難なタスクを可能な限り実行可能にするメカニ ズムを持つことが望ましい。図1は，本研究の一環で 開発中の倒立振子型アシストロボットI-PENTAR が 実現目標とするタスクの代表的な例である．同図にお いて，I-PENTAR は双腕を利用して起立・着座切替え 動作，床上の物拾い，小物のハンドリング，重量物の 持ち上げ等を実現目標とするが，従来のマニピュレー 夕機構を用いてはこれらのタスクを実行することは 困難である．本研究で開発するマニピュレータには， I-PENTARが上記のタスクを実行するのに適切なメ力 ニズムを有することが求められる.

\section{3. 軽量高機能 8 自由度マニピュレータ}

3.1 基本仕様図2, 図 3 に開発した軽量 8 自由 度双腕マニピュレータの外観及びその軸構成を, 表 1 に基本仕様を示す．各マニピュレータはアーム 5 自由 度 $\left(J_{0} \sim J_{4}\right)$, 手首 3 自由度 $\left(J_{5} \sim J_{7}\right)$ の総 8 自由度を有 する.アームには肩 2 自由度 $\left(J_{0}, J_{1}\right)$, 时 2 自由度 $\left(J_{3}\right.$, $J_{4}$ )の他に上椀 (upper arm) に伸縮自由度が設けらてい る.これにより， $J_{0}-J_{4}$ 間長さが通常時 $0.304[\mathrm{~m}]$ から 伸長時 $0.404[\mathrm{~m}]$ まで可変する特徵を持つ. 各関節は, メンテナンス及びハーネス処理を容易にするためにア クチュエータを含めて全関節のパーツがモジュール化 され，多関節にも係わらずマニピュレータ本体がシン プルな構成となっている.アクチュエータは手先の動 作精度を高めるために，DCモータとハーモニックギア 


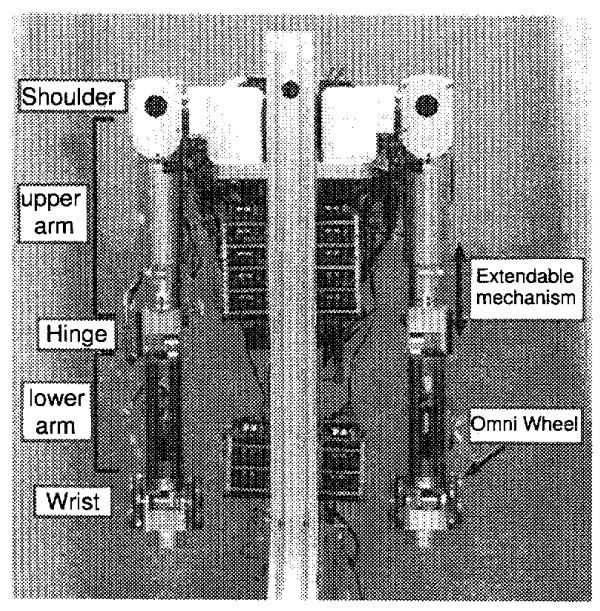

Fig. 2 A light-weight 8 D.O.F dual manipulator

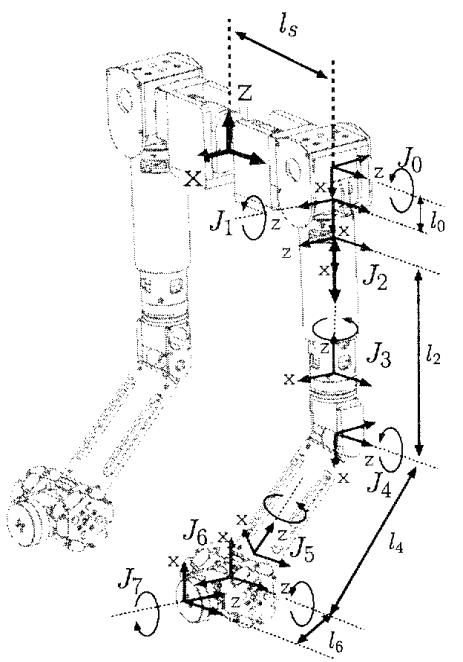

Fig. 3 Joint configuration of the prototype manipulator

Table 1 Basic specification of the manipualtor

\begin{tabular}{lcl}
\hline Weight & {$[\mathrm{kg}]$} & 3 \\
Length & {$[\mathrm{mm}]$} & $569($ Extended:669) \\
D.O.F & & 8 (Arm:5, Wrist:3) \\
Pay load & {$[\mathrm{kg}]$} & 1.75 \\
\hline
\end{tabular}

の組み合わせを採用した．各マニピュレータの全重量 は $3[\mathrm{~kg}]$ であり，可搬重量 $1.75[\mathrm{~kg}]$ が実現できるよう にモータ及び減速機を組み合わせて各関節のアクチュ エータを構成した．表 2,3 にアクチュエータ及びリ ンクパラメータを示す。. 以降, 前述した I-PENTARの 代表的なタスクを実行するために設けられたマニピュ レータの特徵的なメカニズムについて述べる。

3.2 伸縮自由度空間中の対象物の位置及び姿 勢を決めるためにマニピュレータに必要な自由度は 6 自由度であるが, 衝突回避や最適ブレーキ, 器用な動
Table 2 Specification of actuators

\begin{tabular}{l||cccc}
\hline Joint & $\begin{array}{c}\text { Motor } \\
{[\mathrm{W}]}\end{array}$ & Reducer & $\begin{array}{c}\tau_{\max } \\
{[\mathrm{Nm}]}\end{array}$ & $\begin{array}{c}\dot{\theta}_{\max } \\
{[\mathrm{rad} / \mathrm{s}]}\end{array}$ \\
\hline \hline$J_{0}$ (sh,p) & 17.5 & $250(\mathrm{HD})$ & 30 & 24 \\
$J_{1}$ (sh,r) & 17.5 & $250(\mathrm{HD})$ & 30 & 24 \\
$J_{2}$ (linear) & 4.5 & $19(\mathrm{PL})$ & 0.2 & 547 \\
$J_{3}$ (hi,y) & 12 & $100(\mathrm{HD})$ & 8 & 70 \\
$J_{4}$ (hi,p) & 12 & $250(\mathrm{HD})$ & 13 & 28 \\
$J_{5}$ (wr,y) & 3.5 & $129(\mathrm{PL})$ & 3.1 & 50 \\
$J_{6}$ (wr,p) & 4 & $200(\mathrm{HD})$ & 1.9 & 40 \\
$J_{7}$ (wr,y) & 4 & $157(\mathrm{PL})$ & 1 & 50 \\
\hline
\end{tabular}

HD: Harmonic gear, PL: Planetary gear

sh: shoulder, hi: hinge, wr: wrist

r: roll, p: pitch, y: yaw

Table 3 Link parameters

\begin{tabular}{cccccc}
\hline Link & $l_{s}$ & $l_{0}$ & $l_{2}$ & $l_{4}$ & $l_{6}$ \\
\hline Length $[\mathrm{m}]$ & 0.161 & 0.031 & 0.273 & 0.207 & 0.058 \\
\hline
\end{tabular}

作等を実現するためには罙長自由度が必要である。IPENTARに扔いても，一般的な生活支援タスクに関し ては 1 自由度の圥長自由度を含む 7 自由度のマニピュ レータがあれば十分である，しかし，倒立機構の特性 上, 起立・着座, 重量物の持ち上げ，床面上のごみ拾 いなど，腰を大きく曲げるタスクや地面にハンドを接 地する動作においては，アームの長さを自由に調節で きる自由度を有した方がより効率的かつ確実に作業が 実行できると考えられる．特に，後述するが，重量物 の持ち上げ作業等でマニピュレータの肘関節を固定す る必要がある重作業時には，ハンドを対象物に拘束し た状態でロボット全体の重心を動かせる必要があり， アームの伸縮自由度は必需的である。

伸縮自由度を設計する際には，マニピュレータに要 求される機能を考慮して伸縮量を選定する必要がある. まず，前述の着座や床面上のごみ拾い等の目標動作を 実現するためにも，バランス状態，つまり，マニピュ レータを含むロボット全体の合成重心を倒立付近に維 持しながらアーム先端を接地することができるアーム 全長が必要である，一方，直立姿勢 (気をつけの姿勢) の場合は，手首先端に装着されるハンドが地面に接す る等移動時邪魔にならないように，ハンド先端が地面 から一定距離離れるアーム長さを持つことが望ましい. 本研究では，前者に必要なアーム長を最長長さ，後者 に必要な長さを最短長さとして，シミュレーションに より伸長量を選定した.

図 4 にシミュレーションで用いた腰付き倒立振子型 


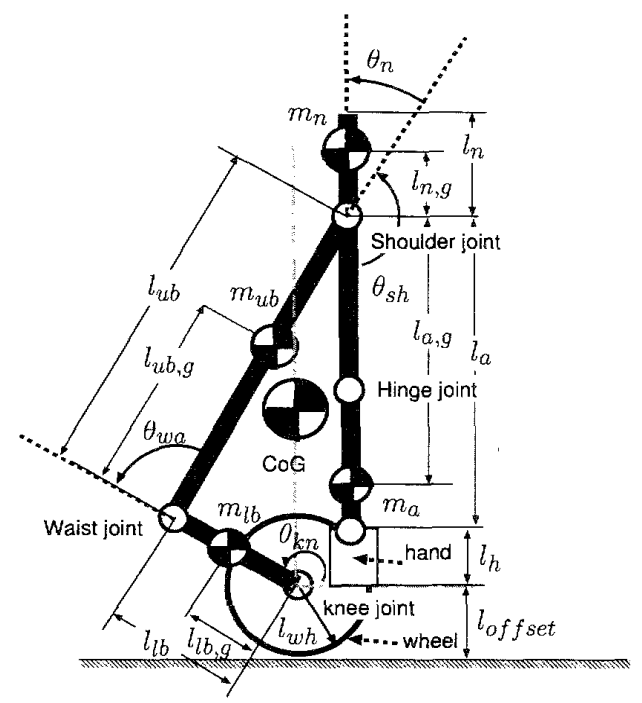

Fig. 4 An inverted pendulum type robot model for the decision of the length of an arm

Table 4 Parameter values for the model

\begin{tabular}{lll|l}
\hline & \multicolumn{1}{c|}{ Parametar } & Value \\
\hline \hline$l_{w h}$ & Wheel radius & {$[\mathrm{m}]$} & 0.1 \\
$l_{l b}$ & Length of a lower body & {$[\mathrm{m}]$} & 0.2 \\
$l_{u b}$ & Length of an upper body & {$[\mathrm{m}]$} & 0.4 \\
$l_{a}$ & Length of an arm & {$[\mathrm{m}]$} & \\
$l_{n}$ & Length of a neck & {$[\mathrm{m}]$} & 0.15 \\
$l_{l b, g}$ & Dist. of CoG of a lower body & {$[\mathrm{m}]$} & 0.16 \\
$l_{u b, g}$ & Dist. of CoG of an upper body & {$[\mathrm{m}]$} & 0.33 \\
$l_{a, g}$ & Dist. of CoG of an arm & {$[\mathrm{m}]$} & 0.4 \\
$l_{n, g}$ & Dist. of CoG of a neck & {$[\mathrm{m}]$} & 0.075 \\
$m_{l b}$ & Mass of a lower body & {$[\mathrm{kg}]$} & 3.5 \\
$m_{u b b}$ & Mass of un upper body & {$[\mathrm{kg}]$} & 15 \\
$m_{a}$ & Mass of an arm & {$[\mathrm{kg}]$} & 6 \\
$m_{n}$ & Mass of a neck & {$[\mathrm{kg}]$} & 1.5 \\
$\theta_{k n}$ & angle of a knee & {$[\mathrm{deg}]$} & \\
$\theta_{w a}$ & angle of a waist & {$[\mathrm{deg}]$} & \\
$\theta_{s h}$ & angle of a shoulder & {$[\mathrm{deg}]$} & \\
$\theta_{n}$ & angle of a neck & {$[\mathrm{deg}]$} & \\
\hline
\end{tabular}

ロボットのモデルを, 表 4 に各パラメータを示す. 同 モデルは車輪, ボディー,アーム, 頭で構成され, ボ ディーは腰関節により上部ボディーと下部ボディーに 分かれ，下部ボディーは車輪と軸を共有する．モデル での $\theta_{s h}$ は図 2 において $J_{0}$ の回転角, アームの全長 $l_{a}$ は $J_{0}$ から $J_{6}$ までの長さに相当する.

まず, アームの最短長さ $l_{a, \min }$ の選定において，八 ンド長さ $l_{h}$ 及びハンド先端の地面からのオフセット距 離 $l_{\text {offset }}$ の合計を $0.2[\mathrm{~m}]$ に仮定すると, ロボットの直

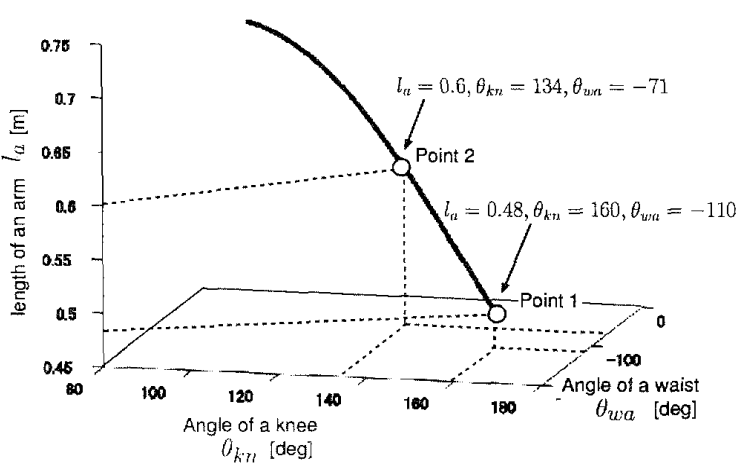

(a) Relation among $l_{a}, \theta_{\psi k}$, and $\theta_{k n}$

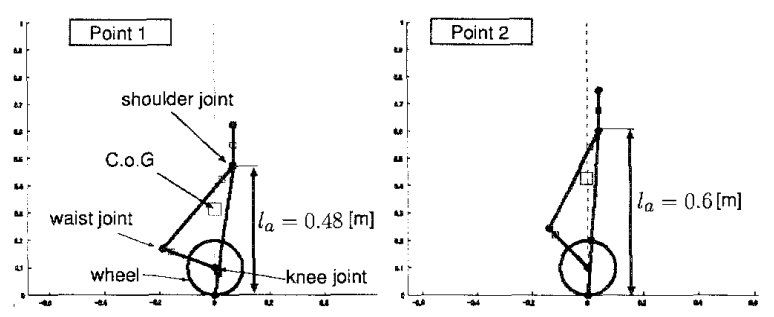

(b) Posture of the robot model at point 1 and 2

Fig. 5 Simulation results for the decision of extendable length of the arm

立姿勢 $\left(\theta_{k n}, \theta_{w a}, \theta_{s h}, \theta_{n}\right)=(90,0,-180,0)$ でハンド先 端が地面に接しないためには, $l_{a, \min }=0.5[\mathrm{~m}]$ が妥当 である。

次に, アーム最長長さ $l_{a, \max }$ を選定するためのシミュ レーションを行う. シミュレーションでは，ロボットの 合成重心を車軸上に維持し，アームの先端を地面に固 定した状態で腰関節を限界角度まで回転させた場合の 肩関節からアーム先端までの距離を求めた．膝関節角 $\theta_{k n}$ 及び腰関節角 $\theta_{w a}$ の可動範囲はそれぞれ $(0,180)$, $(-110,0)$ であり, 首関節角 $\theta_{n}$ は頭部が常に地面に垂 直になるように角度を設定した. 図 5 にシミュレーショ ン結果を示す。図 5(a)において, 点 1 は腰関節が可動 限界の場合であり，この時の肩関節から地面までの距 離が 0.48[m] であることが分かる.これは, $0.48[\mathrm{~m}]$ の 長さのアームの場合でもロボットがバランスを維持し ながらアーム先端に位置する手首を接地することが可 能であることを意味する. しかし，実際の運用を想定 した場合, 腰関節を可動限界まで回転させることはバ ランス制御及び腰関節への負荷上好ましくないので, グラフ上の点 2 の状態を選択する. 点 2 は膝と腰関節 

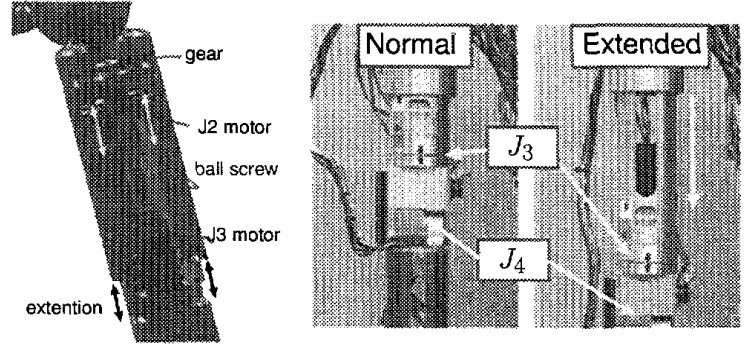

Fig. 6 An extendable mechanism
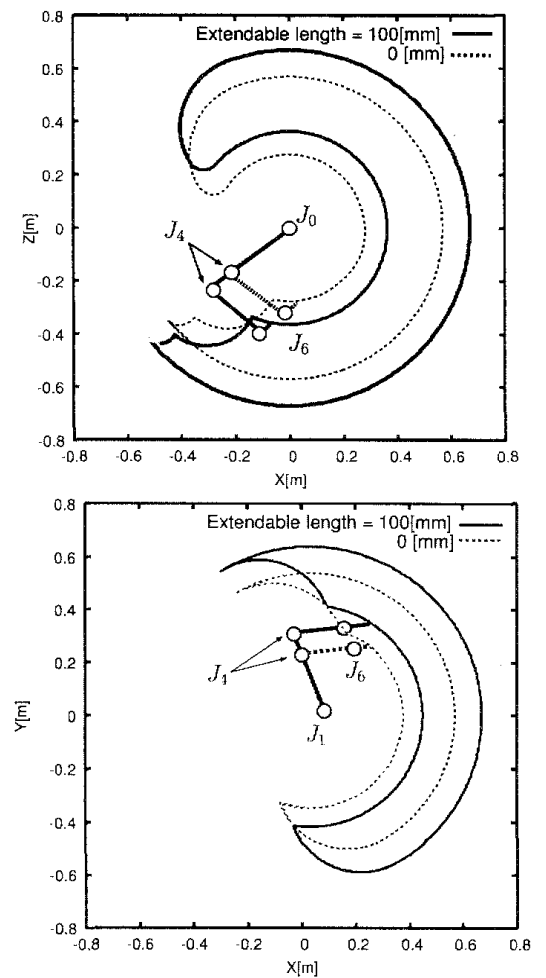

Fig. 7 Workspace of the prototype manipulator with an extendable joint: $X-Z$ space(Up), $X-Y$ space(Down)

が各々 $134[\mathrm{deg}],-71[\mathrm{deg}]$ の状態であり, 腰関節が可 動限界から 39[deg] 離れている．この時の肩から地面 までの距離は $0.6[\mathrm{~m}]$ である.

これまでの検討結果を踏まえて，アームの長さを通 常時 $0.5[\mathrm{~m}]$, 伸長時 $0.6[\mathrm{~m}]$ になるように伸縮自由度 の伸縮量を $0.1[\mathrm{~m}]$ に決定した.これにより，倒立振子 型ロボットは通常時の直立姿勢でもハンド先と地面が 干渉せず，又，アームを伸ばすことで腰関節を可動限 界まで曲げることなく手首の接地が必要な作業が実現 できる。

図 6 に製作したマニピュレータの伸縮関節の外観及 び構造を示す。上腕リンク内の上部に位置する伸縮駆 動用のアクチュエータ $\left(J_{2}\right)$ により 2 本のボールスク

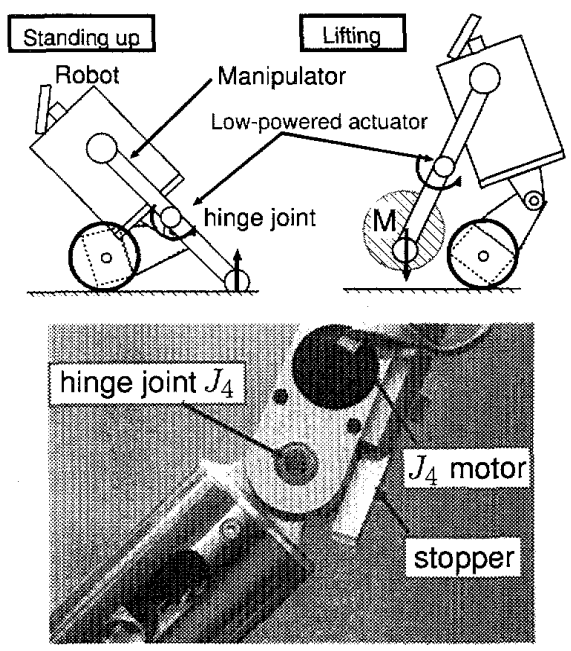

Fig. 8 A hinge stopper for a heavy task

リューを回転させると，ボールスクリュー上のレール が移動し， $J_{3}$ 以降のアームが伸縮する機構となって いる.

伸縮自由度を設けることで，接地等の動作の他に一 般的作業におけるマニピュレータの作業空間の拡大も 期待できる。図 7 に，開発したマニピュレータの各 関節可動範囲とリンクパラメータから求めたマニピュ レータ 1 本分の作業領域を示す。同図における点線 は伸縮自由度がない通常時のマニピュレータの作業領 域，実線は伸縮自由度を用いてマニピュレータを伸ば した時の作業領域である。両領域を合わせた領域がマ ニピュレータの総作業領域であり, 伸縮自由度を持つ ことにより作業領域が大きく拡張されていることが確 認できる.

3.3 时ストッパー＼cjkstart開発したマニピュレータは安 全性を高めるために基本的に低パワーのモータを採用 している. 特に肘関節はアクチュエータの重量増加に よるマニピュレータの慣性質量の増加を避けるために, 可搬重量を考慮した低パワーモータを装着している. 一方，I-PENTAR はマニピュレータを用いたロボット 本体の押し上げ，重心を用いた重量物持ち上げ等の重 作業を想定している.このような作業の場合，図 8(上) に示すように，肘関節 $\left(J_{4}\right)$ には大きな曲げモーメント が発生するため, 低パワーの肘関節では動作の実行 が困難となる.この問題に対好するために，マニピュ レータの肘関節に図 8 (下) に示す重作業用のメカニカ ルストッパーを設けている。 ロボットは，时関節に大 きなモーメントがかかるような重作業を実行する際, 肘関節をメカニカルストッパーに固定した状態で，肩 関節 $\left(J_{0}\right)$ のみの 1 リンクマニピュレータとして作業を 行う. 通常, 倒立振子型ロボットの自重を用いた重量 

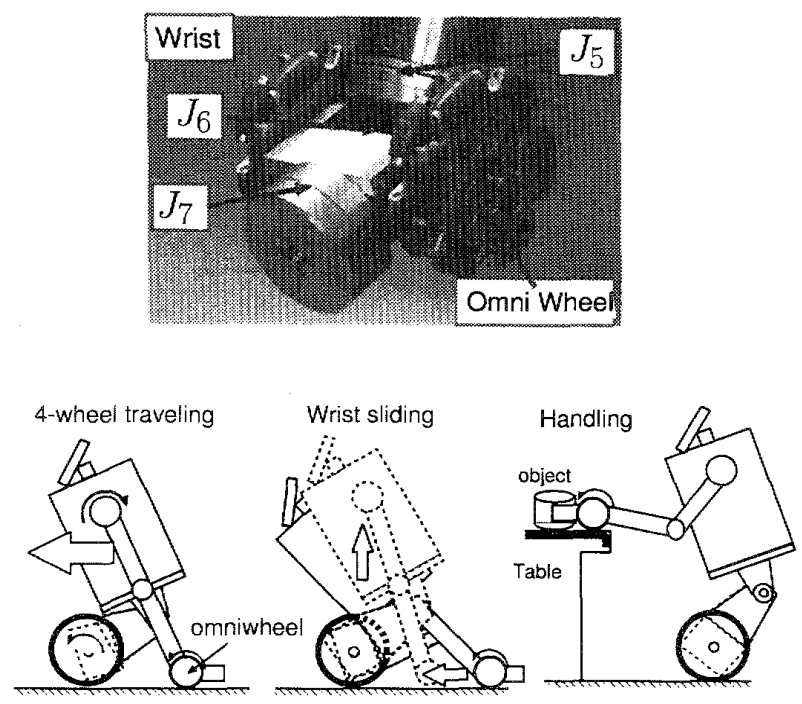

Fig. 9 An omni wheel on the wrist

物持ち上げ作業において，搭載したマニピュレータが 1 リンクで, かつ, 先端のハンドが対象物に固定され ると，ロボットは閉リンク系となり重心を自由に動か すことができなくなる．このような場合でも，提案す るマニピュレータは伸縮自由度をうまく用いることに よりロボットの重心を移動することができ，自重の効 率的利用が可能である.

3.4 手首オムニホイル 倒立振子型ロボットは 移動したり待機したりするために動的安定制御を常に 行わなければならない，したがって，テーブル上の小 物のハンドリングや待機状態，不整地などの移動等実 環境への導入を想定した場合，実用上大きなデメリッ トを持つ. この問題に対処するために, マニピュレー 夕の手首 $J_{6}$ 関節の回転軸と同一線上に図 $9($ 上) に示す オムニホイルを設けたユニークな機構を採り入れた。 これにより, I-PENTARは, 図9(下)に示すように, 車 輪とオムニホイルを用いた 4 輪安定走行, 静的状態で の重心移動のための手首スライディング等の動作が行 える. また，小物の安定なハンドリン等細かな作業の 場合は，オムニホイルをテーブル上に載せ，車輪とオ ムニホイルの 3 点支持の安定状態で作業を行うことが 可能である.

\section{4. 制御システム}

図 10 にマニピュレータの制御システムの構成図 を示す、制御システムは，リアルタイム linuxである ARTLinux を OS として, FPGA に PWM 発生器と力 ウンターを実装し, 外部のモータドライバやエンコー 多等と通信を行う構成となっている. 内部コントロー ラは, TCP/IP 通信により外部のクライアントから指

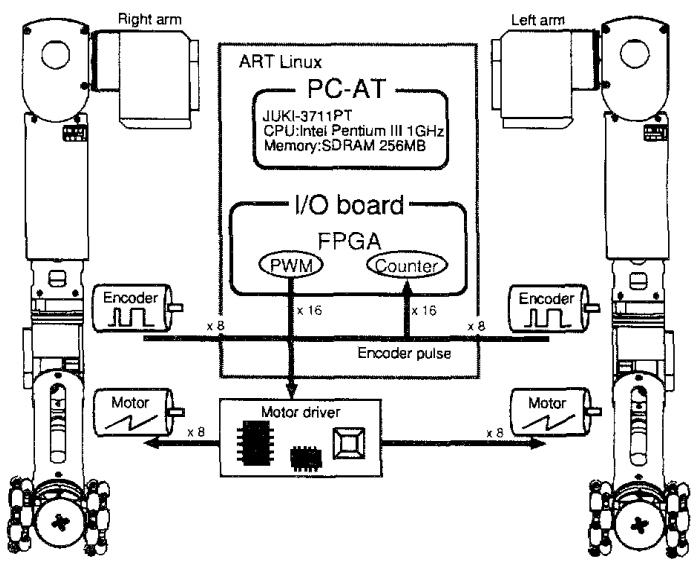

Fig. 10 A structure of a control system

令值を取得し各関節の制御を行う。

マニピュレータの基本制御は，PID 制御を適用した 関節空間における角度制御を基本とし, 制御式は次式 で表される.

$$
\tau=K_{p}\left(\theta_{d}-\theta\right)+K_{v}\left(\dot{\theta}_{d}-\dot{\theta}\right)+K_{i} \int\left(\theta_{d}-\theta\right) d t
$$

ここで， $\tau$ は制御入力， $K_{p}, K_{v}, K_{i}$ はそれぞれ比例, 微分，積分ゲインである．また， $\theta_{d}, \theta$ は目標関節角 度, 関節角度を表す。一方，作業空間における位置・ 姿勢の制御法に関しては，次式で示すヤコビアンの疑 似逆行列を用いた冗長制御法を適用する。

$$
\begin{aligned}
& \dot{\theta}_{d}=J^{\#} \dot{x}_{d} \\
& \theta_{d}=\int \dot{\theta}_{d}
\end{aligned}
$$

ここで, $J^{\#}=J^{T}\left(J J^{T}\right)^{-1}, \dot{x}_{d}$ は作業空間における速度 指令值である.

上記の制御システム及び制御法を用いて簡単な 動作実験を行った。動作実験では, 各関節を $J_{0}$ か ら $J_{7}$ まで順次に目標角度まで稼働した。図 11 に 各関節ごとの動きを撮影した動画のスナップ画像 及び左マニピュレータの各関節の角度プロファイ ルを示す. 各関節の最終目標角度は $J_{0}$ から順に, $(-20,20,3000,-30,-30,-40,-30,90)[\mathrm{deg}]$ であ る. 同実験結果から構築した制御システムにより各関 節の角度制御がうまく行われていることが確認できる.

\section{5. 結語}

本論文では，倒立振子機構を持つ人間共存型ロボッ トへの導入を目的として開発した軽量多機能双腕マニ ピェレータについて述べた。開発したマニピュレータ は, 8 自由度を有しながら全重量が $3[\mathrm{~kg}]$ の軽量であ 

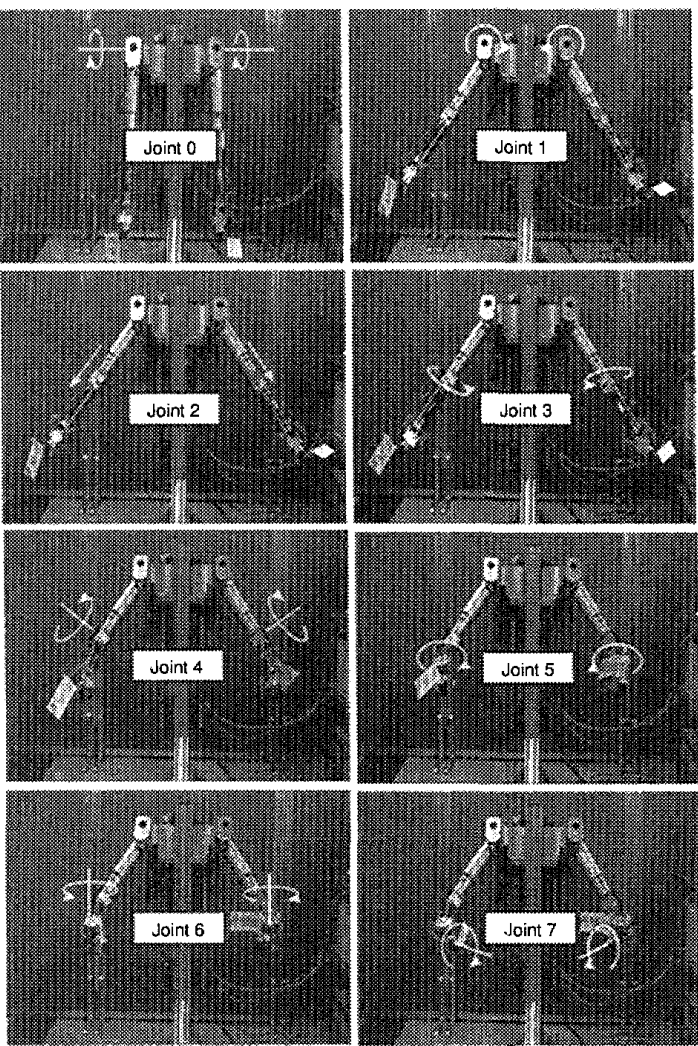

(a) Snap shot of the joint motion

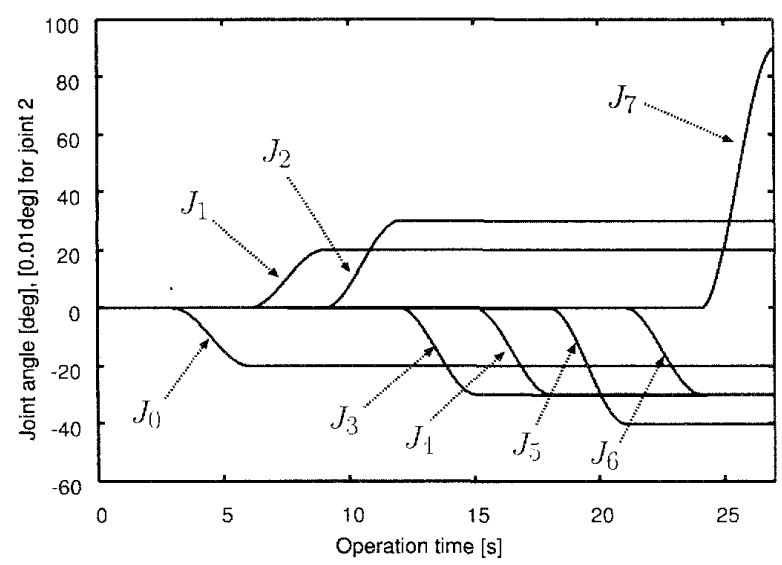

(b) Profile of each joint angle of a left manipulator

Fig. 11 Experimental result of motion control

り，可搬重量 $1.75[\mathrm{~kg}]$ が実現できるコンパクトな設計 となっている．さらに，伸縮機構，メカニカルストッ パー, 手首オムニホイルなどの機構を有し, 倒立振子 型アシストロボットによる多様なタスク実行を可能に する. 本研究で開発したマニピュレータは，これまで 移動プラットフォームに留まった倒立振子ロボットを
様々な人間支援が実行できる人間共存型ロボットへ活 躍の場を広げるのに貢献すると期待できる.

\section{文献}

(1) Ymafuji,K., Kawamura,T., Postural Control of a Monoaxial Bicycle, Journal of the Robotics Society of Japan, Vol.7, No.4(1988),pp.74-79.

(2) Matsumoto,O., Kajita,S., Estimation and Control of Attitude of a Dynamic Mobile Robot Using Internal Sensors, Journal of the Robotics Society of Japan, Vol.8, No.5(1990), pp.37-46.

(3) Ha,Y., Yuta,S., Indoor Navigation of an Inverse Pendulum Type Autonomous Mobile Robot with Adaptive Stabilization Control System, Proccdings of the 4th International Symposium on Experimental Robotics, (1995), pp.331336.

(4) Bryan,J.T., Patrick,D., Roderic,G., Static Analysis of Contract Forces With a Mobile Manipulator, Proceedings of the International Conference on Robotics and Automation,(2006), pp.4007-4012.

(5) Matsumoto,O., Kajita,S., and Tanie,K., Cooperative Behavior of a Mechanically Unstable Mobile Robot for Object Transportation, Transaction of the Japan Society of Mechanical Engineers, Series A, Vol.64(c), No.628(1998), pp.164-171.

(6) Ishigura,H., Ono,T., Imai,M., Maeda,T., Kanda,.T, and Nakatsu,R., Robovie: A robot generates episode chains in our daily life, Proceedings of the International Symposium on Robotics, Vol.28, No.6(2001), pp.1356-1361.

(7) Hosoda,Y., Egawa S., Tamamoto,J., Basic design of human-symbiotic robot EMIEW, Proceedings of the 2006 IEEE/RSJI International Conference on Intelligent Robots and Systems, Vol.1-12, (2006-9), pp.5079-5084.

(8) Jeong,S., Takahashi,T., Wheeled Inverted Pendulum Type Assistant Robot: Design Concept and Mobile Control, Intelligent Service Robot, Vol.1, No.4(2007), pp.313-320.

(9) Jeong,S., Takahashi,T., Wheeled Inverted Pendulum Type Assistant Robot: Inverted Mobile, Standing, and Sitting Motions, Proceedings of the 2007 IEEE/RSJ International Conference on Intelligent Robots and Systems, Vol.1-9, (2007-10), pp.1932-1937.

(10) Jeong,S., Takahashi,T., Stable and Quick Standing Motion of I-PENTAR by Whole-body Motion with Force Control, Proceedings of the 2008 IEEE/RSJ International Conference on Intelligent Robots and Systems, Vol.1-3, (2008-9),pp.199-204.

(11) Luca,A.D., Alin A., Haddadin,S, and Hirzinger,G., Collision Detection and Safe Reaction with the DLR-3 Lightweight Manipulator Arm, Proceedings of the 2006 IEEE/RSJ International Conference on Intelligent Robots and Systems, Vol.1-12, (2006-10), pp.1623-1630.

(12) Nakamura,Y., Hanafusa,H., and Yoshikawa,T., Task Priority Based Redundancy Control of Robot Manipulators, The International Journal of Robotics Research, Vol.6, No.2(1987), pp.3-15. 